\title{
Healthcare Workers' Compliance with Hand Hygiene after the Introduction of an Alcohol-Based Handrub
}

\author{
Chittaro M ${ }^{1}$, Calligaris L ${ }^{2}$, Farneti F ${ }^{2}$, Faruzzo A ${ }^{1}$, Panariti $\mathrm{M}^{2}$, Brusaferro S ${ }^{2}$ \\ ${ }^{1}$ University Hospital of Udine, Udine, Italy \\ ${ }^{2}$ DPMSC, University of Udine, Italy \\ doi:10.3396/ijic.V5i1.002.09
}

\begin{abstract}
Hand hygiene for healthcare workers (HCW) is a basic measure of hospital infection control although compliance is extremely low. We studied the introduction of an alcohol-based handrub for HCWs in intensive care, surgical and medical areas of a university hospital. Three surveys were performed: before, 7, and 30 days after introducing the product. Overall, 432 nurses' working hours and 3451 hand hygiene occasions were observed. Compliance increased significantly from $19.3 \%(244 / 1262)$ in survey 1 to $28.1 \%(314 / 1119)$ and $27.1 \%(288 / 1070)(p<0.01)$ in surveys 2 and 3, respectively. Compliance was more frequent after performing a nursing procedure $(39.1 \%, 443 / 1133)$ than before it $(15.7 \%, 329 / 2092)(p<0.01)$. Furthermore, compliance significantly decreased with the increase in number of hand hygiene occasions per nurse/hour before handrubbing had been introduced [30.2\% 0-7 occasions/h vs $21.8 \% \geq 8$ occasions/h $(p<0.05)]$. Gender did not affect compliance. Results are consistent with other studies on the problem of limited adherence to hand hygiene guidelines. Overall compliance was $<30 \%$, and the higher compliance observed after nursing procedures shows that the staff are more concerned with their own safety than that of patients.
\end{abstract}

\section{Keywords}

hand hygiene, handrub, compliance, hospital, healthcare worker.

\section{Introduction}

Hand hygiene by healthcare workers ( $\mathrm{HCW})$ is a basic measure of hospital infection control. ${ }^{1}$ Nevertheless, despite its ease of execution, the awareness of personnel about its preventive role, usefulness, and low cost, ${ }^{2}$ compliance of HCWs with hand hygiene is extremely low. ${ }^{3,4}$
Improving attitudes concerning hand hygiene in healthcare facilities is a 'hot' issue for national and international authorities. ${ }^{5-7}$ We studied the effect of introducing an effective handrubs in improving hand hygiene in nursing staff in a high-specialization university hospital. Secondary objectives were: to quantify the hand hygiene occasions among nurses in different care

\section{Corresponding author}

Michele Chittaro, Medical Direction, Department of Clinical and Experimental Pathology and Medicine (DPMSC), University of Udine, P.zzale S. Maria della Misericordia, 1533100 UDINE - ITALY

Tel: 39432 559879, Fax: 39432 559239, Email: michele.chittaro@med.uniud.it 
areas; to define personnel's adherence to guidelines on these occasions; to evaluate the most suitable areas or situations to introduce handrubs; and to identify 'hot spots' regarding hand hygiene in different care situations and suggest possible solutions.

\section{Methods}

The observational study was carried out in a 313-bed university hospital. It took place in three localities: the intensive care area (five beds -20 nursing staff); the surgical area (42 beds -20 nurses); the medical area (33 beds -17 nurses). We chose these sites because intensive care units are the most studied in the literature, while the surgical and medical areas are widespread both in Italian and international hospitals. The study, consisting of three phases, examined the number of hand hygiene occasions among the nursing staff. The first observation took place in February/March 2004, with the added aim of validating the survey. The second observation took place in June 2005, seven days after the introduction of an alcohol-based handrub, and the third in July 2005, 30 days later; each survey lasted for a total of 48 hours spread over six days.

The hand hygiene occasions have been summarized as 'before' and 'after' the following eight procedures: vascular assistance, respiratory assistance, urinary assistance, wound medication, contacts between body fluids and injured skin, personal hygiene, direct and indirect contact with the patient.

Only the director and the nurses' coordinator of the clinical area knew the purpose of the study. Nursing staff were not informed because we did not want them to modify their behaviour knowing they were observed (Hawthorne effect). The observers tried not to hinder the staff in their work and when asked, said they were investigating the staff workload.

The five observers were from medical and nursing staff unrelated to the units in which the observations took place. They had been trained to conduct the survey, and at the end of each survey-day they met to compare experiences. Each observer worked in all three areas. We chose to observe nursing staff because they comprise the professional category with the most numerous opportunities for hand hygiene. Observers had to fill in a grid on the form, with the hand hygiene occasions observed for every nurse surveyed.

Some assumptions were made to standardize the surveillance method: use of gloves alone could not replace hand hygiene, ${ }^{9,10}$ if the observation time ended before assistance to the patient had been concluded, the observation lasted until the procedure was finished; the procedure was considered finished when the nurse left the patient, began nursing on another site, touched other surfaces or handled permanent devices. Hand hygiene between two consecutive procedures was considered only once and classified in 'before' nursing. This avoids an overestimation of the hand hygiene occasions. The 'after' hand hygiene, to be classified as such, had to be done just after nursing.

Our university hospital has had a protocol for hand hygiene and the use of gloves since 1999. During phase 1 of the study alcohol-based handrub was not used. It was distributed by the nurses' coordinator to the nursing staff between phases 1 and 2 .

The hand hygiene occasions were observed during day shifts from Monday to Saturday, from 8.00 to 20.00. Nights were excluded, since there is less opportunity for hand hygiene. Every observer surveyed two different nurses for $2 \mathrm{~h}, 1 \mathrm{~h}$ each (either in the surgical, medical or intensive area). Eight out of the 12 available daytime hours were chosen (four observers per operative unit), so that every observation should be scheduled four times per operative unit. In practice, 24 periods of $2 \mathrm{~h}$ were observed in each operative unit, out of the 36 available. In each phase the observer surveyed six sessions, possibly in different daytime hours.

A few days before starting the survey, we evaluated the nursing staff's shifts and selected those that allowed us to observe each person for approximately the same number of occasions. Hand hygiene occasions were defined as all those situations where hand hygiene is suggested in the published guidelines. ${ }^{7}$ Adherence to the practice was the dependent variable, and was defined considering real hand hygiene compared to all occasions identified. Other variables, independent or predictive, were: operative unit, day shift, day of the week, type of nursing, activity index (number of hand hygiene occasions per hour), gender. 
Data were processed using the software program Chicago, IL,USA for SPSS version 11.0. The statistical analysis was performed using the chi-square test to test proportions and the Kruskal-Wallis test when the distribution of data could not be considered normal, assuming significant a $p$ value $<0.05$.

\section{Results}

Overall, 432 hours (144 hours per phase) were observed, divided into 216 sessions of two hours each (72 sessions per phase). Table I shows the distribution of HCWs surveyed.

The mean of hand hygiene occasions per working hour in all three phases was $8.61(\mathrm{SD} \pm 4.78$, range $1-31)$ - 9.01 (SD \pm 4.89 , range 1-23) in phase 1, $8.35(\mathrm{SD} \pm$ 4.44 , range $1-23$ ) in phase 2 and $8.42(\mathrm{SD} \pm 5.01$, range 2-31) in phase 3 . There were no significant differences, nor was any significant difference per working hour seen among the different areas; the mean was 8.56 (SD \pm 4.53 , range 1-23) in the intensive care area, 7.65 (SD \pm 4.44 , range 1-31) in the surgical area, and 9.64 (SD \pm 5.20 , range 1-24) in the medical area.

Table II describes compliance for hand hygiene in the three phases of the study. Total compliance increased significantly from $19.3 \%$ (phase 1 ), to $28.1 \%$ and $27.1 \%$, respectively, in phases 2 and 3 . In the intensive care area a significant drop of compliance occurred $(p<0.05)$ in the third phase. In the surgical area, there was a significant increase of total compliance, and in the medical area there was a similar compliance in the first two phases (18.1 and 18.6\%) which increased in the third phase $(p<0.01)$.

The mean compliance per hour for the three phases was $26.4 \%$ ([SD \pm 22.4 , range 0-100); $22.3 \%$ (SD $\pm 22.4)$ in phase $1,29.3 \%$ (SD \pm 2.1 , range $0-83)$ in phase 2 and $27.9 \%$ (SD \pm 23.5 , range $0-100$ ) in phase 3 . The compliance in the second and third phase was significantly higher than the first phase $(p<0.01)$. No statistically significant differences were found between males and females, the values being $26.5 \%$ ( $\mathrm{SD}_{ \pm}$ 25.1, range 0-89) for males and 26.4\% ( $\mathrm{SD}_{ \pm}$21.8, range $0-100)$ for females. Even after stratifying data for each phase, there were no differences in gender, and compliance rose homogeneously in both males and females between phases 1 and 3. Male compliance went from $22.2 \%$ (SD \pm 20.6 , range $0-75)$ in phase 1 to $30 \%$ ( $\mathrm{SD} \pm 26.6$, range $0-71$ ) in phase 2 , to $27.9 \%$ (SD \pm 28 , range $0-89$ ) in phase 3. Female compliance went from $22.3 \%$ ( $S D \pm 21.5$, range $0-100)$ in phase 1 to $29.1 \%$ ( $\mathrm{SD} \pm 21.2$, range $0-83$ ) in phase 2 , to $28 \%$ ( $\mathrm{SD} \pm 22.3$, range $0-100)$ in phase 3 .

Table III shows the compliance of hand hygiene 'before' and 'after' nursing tasks. It is evident that for some categories the compliance increased between the first and second phases of the study (vascular assistance, respiratory assistance, wound medication, direct and indirect contact with the patient) although statistical significance was only reached for the vascular assistance $(p<0.01)$.

Hand hygiene was more frequent 'after' a procedure than 'before' it $(p<0.01)$. In phase 1 , the HCWs did the hand hygiene $10.6 \%$ (84/795) of the time 'before' a procedure and $34 \%$ (135/397) of the time 'after' a procedure $(\mathrm{p}<0.01)$; in phase $2,21 \%(137 / 653)$ of the time 'before' a procedure and 39.5\% (143/362) of the time 'after' it $(p<0.01)$; in phase $3,16.8 \%(108 / 644)$ of the time 'before' a procedure and $43.9 \%$ (165/374) of the time 'after' it $(p<0.01)$. Overall, handrub was used in $30.2 \%$ of procedures both in the second (95/134) and third phases (87/288). It was used more 'before' [32.1 $\%(44 / 137)$ in phase 2 and $33.9 \%$ (39/115) in phase 3], than 'after' a procedure $[28.8 \%(51 / 177)$ in phase 2 and $27.7 \%(48 / 173)$ in phase 3]; nevertheless, the data are not significant.

Table IV shows the compliance stratified by activity index (the median value of eight occasions/hour defines the two categories in the three study phases. Compliance significantly decreased $(p<0.05)$ with the increase in number of occasions per hour in only the first phase, i.e. before the handrubbing. Only in the intensive care area did compliance decrease significantly with the increase in number of occasions/hour in phase $1(p=0.01)$ and in phase $2(p<0.05)$.

Even seven days after the introduction of the alcoholbased handrub (phase 2), 51\% (23/45) of the personnel had never used it, compared to the $40 \%(16 / 40)$ in phase 3. 


\section{Discussion}

Our results are consistent with other studies reporting the problem of limited adherence to hand hygiene guidelines. In fact, overall compliance was $<30 \%$, within the range of other studies ${ }^{10,11}$ that seldom report percentages $>40 \%{ }^{12,13}$

Ours was a blind study. Since the nurses were unaware of the real aim of the survey, no 'Hawthorne' effect occurred. The only intervention was introduction of an alcohol-based handrub, with no associated strategy, e.g. educational campaigns on hand hygiene with feedback, reminders in wards, etc. The only educational material in the areas surveyed was the hand hygiene guidelines, supplied and updated since 1999.

Although compliance increased after the introduction of the alcohol-based handrub, as in other studies ${ }^{14,15}$ it did not reach satisfactory levels. This could be due to $\mathrm{HCWs}^{\prime}$ belief that gloves replace hand hygiene, at least in the most critical procedures. Pittet lists this among the reasons HCWs give for not being compliant with hand hygiene. ${ }^{16}$

Our nursing staff performed hand hygiene more frequently 'after' a procedure than 'before' it, implying they are more concerned with their own safety than that of patients. The transmission risk of pathogens is feared when it is directed from the patient towards the operator, but not vice versa.

Among the factors related to a lower compliance with hand hygiene, Nobile identifies the intensive care area, because of a higher rate of occasions per working hour. ${ }^{17}$ However, we found no significant statistical differences in the three areas considered, suggesting a homogeneous distribution of workload.

Compliance with hand hygiene increased after the introduction of the alcohol-based handrub in the surgical and medical areas. In the intensive area it remained unchanged in the first two phases, but decreased in the third (Table II). However during that time there were fewer patients and indeed in some shifts the nursing staff had no hand hygiene occasions. A different distribution of hand hygiene occasions could also reflect a different distribution in type. A smaller workload might cause an attention loss translated into less adherence to hand hygiene.

A second factor mentioned by Pittet in relationship to lower compliance to hand hygiene is male gender, ${ }^{16}$ but we found no differences between males and females. A third factor responsible for decreased compliance is a high number of occasions per hour. ${ }^{16}$ In the first phase of our study, in fact, when the workload was heavier, the adherence to hand hygiene was worse. After the introduction of the alcohol-based handrub, the decrease in hand hygiene/handrubbing with the increase in workload is no longer as significant as it was before. Handrubbing is, therefore, particularly useful when the workload is heavy.

Even when the product was available on the wards, many HCWs did not use it (51 and $40 \%$ after 7 and 30 days, respectively). Introducing the product without any associated educational campaign may not have generated a positive attitude to hand hygiene. Resistance to use of hand rubs has been explained by adverse events, such as irritation/allergies ${ }^{18}$ and skin dryness, mostly in the winter months. ${ }^{16}$ However, we performed the study in the summer and no adverse events arose. It would be useful before planning new interventions, to understand the underlying reasons for non-compliance, whether known or not.

\section{Conclusions}

The results of our study are consistent with the data on HCWs' low adherence to the hand hygiene guidelines in the international literature. Analysing attitudes, we found that nursing staff have a perception of infection that cares more about the operator's health than the patient's. Even though we found an increase in compliance, which was maintained for a long time after the introduction of alcohol-based handrub, it did not reach acceptable values. Further measures must accompany the introduction of an alcohol-based handrub. Educational programmes might be useful, since no appropriate hand hygiene culture has been developed to date. Structural (i.e. more washbasins, availability of pocket or bedside handrubs, etc.) and organizational modifications (avoiding understaffing and overcrowding) could also be important in encouraging hand hygiene. A multidisciplinary approach is needed to reach an effective long term result. 
Table I: Distribution of HCWs surveyed

\begin{tabular}{lcccccc} 
& \multicolumn{2}{c}{ Phase I } & \multicolumn{2}{c}{ Phase I I } & \multicolumn{2}{c}{ Phase I I I } \\
\hline Intensive care area & $\mathrm{n}$ & $\%$ & $\mathrm{n}$ & $\%$ & $\mathrm{n}$ & $\%$ \\
\hline Surgical area & 16 & 34.0 & 15 & 33.3 & 16 & 40.0 \\
\hline Medical area & 17 & 36.2 & 13 & 28.9 & 14 & 35.0 \\
\hline Total & 14 & 29.8 & 17 & 37.8 & 10 & 25.0 \\
\hline
\end{tabular}

Table II: Compliance for hand hygiene and handrubbing in the three phases of the study in the three areas surveyed

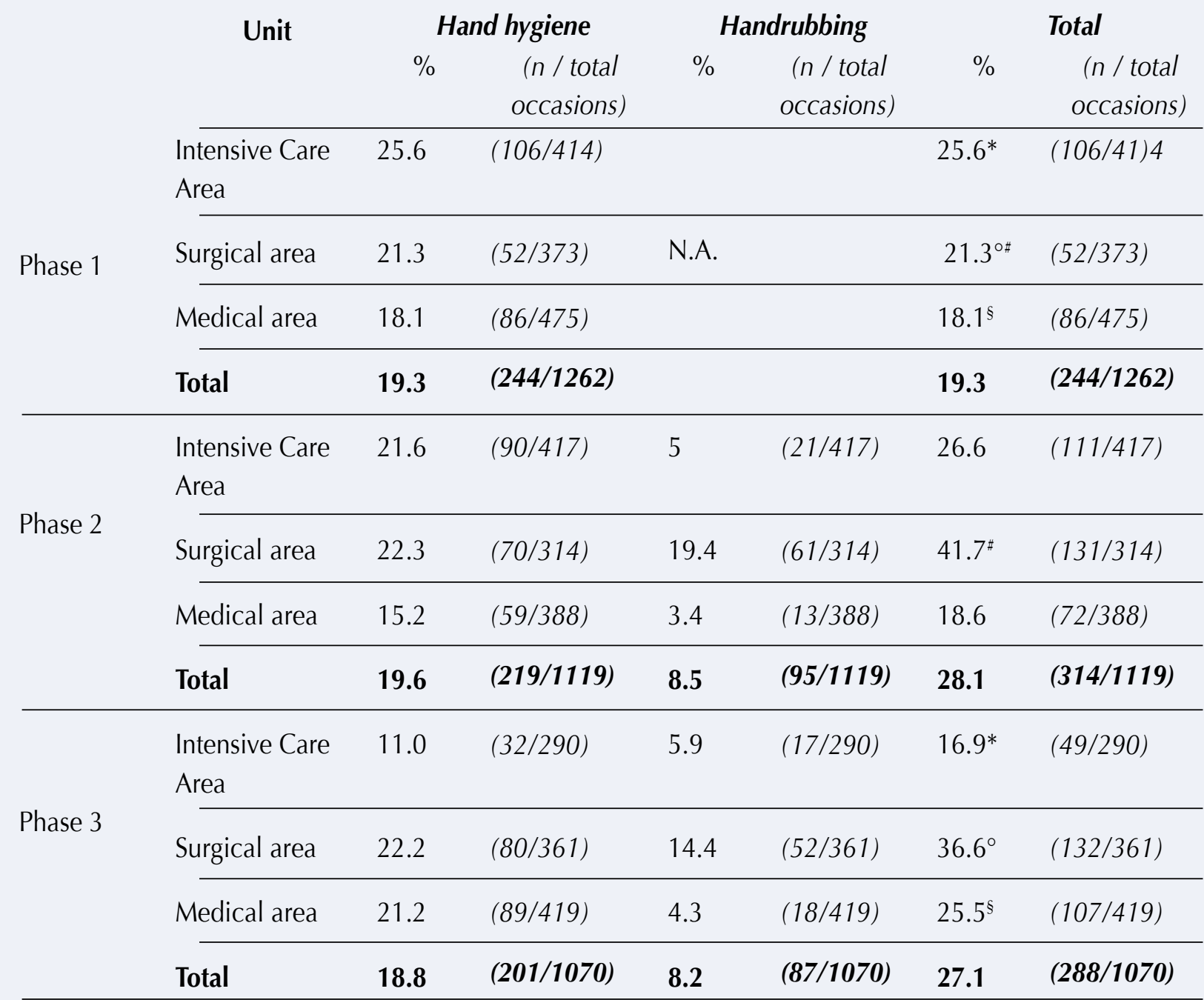

${ }^{*} \mathrm{p}<0.05 ;{ }^{\circ} \mathrm{p}<0.01 ; \S \mathrm{p}<0.01 ; \# \mathrm{p}<0.01$ 
Table III: Compliance of hand hygiene and handrubbing "before" and "after" nursing

\begin{tabular}{|c|c|c|c|c|c|c|c|}
\hline & \multicolumn{2}{|l|}{ Phase 1} & \multicolumn{2}{|l|}{ Phase 2} & \multicolumn{3}{|c|}{ Phase 3} \\
\hline Macro-categories & $\begin{array}{l}\text { hw } \\
\% \\
\text { (n/total } \\
\text { occasions) }\end{array}$ & $\begin{array}{l}\text { hw } \\
\% \\
\text { (n/total } \\
\text { occasions) }\end{array}$ & $\begin{array}{l}\text { hr } \\
\% \\
\text { (n/total } \\
\text { occasions) }\end{array}$ & $\begin{array}{l}\text { tot } \\
\% \\
\text { (n/total } \\
\text { occasions) }\end{array}$ & $\begin{array}{l}\text { hw } \\
\% \\
\text { (n/total } \\
\text { occasions) }\end{array}$ & $\begin{array}{l}\text { hr } \\
\% \\
\text { (n/total } \\
\text { occasions) }\end{array}$ & $\begin{array}{l}\text { tot } \\
\% \\
\text { (n/total } \\
\text { occasions) }\end{array}$ \\
\hline $\begin{array}{l}\text { Vascular } \\
\text { assistance } \\
\text { Respiratory }\end{array}$ & $\begin{array}{l}17.8 \\
(61 / 343)\end{array}$ & $\begin{array}{l}21.4 \\
(76 / 355)\end{array}$ & $\begin{array}{l}9.9 \\
(35 / 355)\end{array}$ & $\begin{array}{l}31.3 \\
(111 / 355)\end{array}$ & $\begin{array}{l}22.2 \\
(78 / 352)\end{array}$ & $\begin{array}{l}9.7 \\
(34 / 352)\end{array}$ & $\begin{array}{l}31.9 \\
(112 / 352)\end{array}$ \\
\hline assistance & $\begin{array}{l}22.2 \\
(8 / 36)\end{array}$ & $\begin{array}{l}23.9 \\
(11 / 46)\end{array}$ & $\begin{array}{l}4.3 \\
(2 / 46)\end{array}$ & $\begin{array}{l}28.2 \\
(13 / 46)\end{array}$ & $\begin{array}{l}23.8 \\
(5 / 21)\end{array}$ & $\begin{array}{l}14.3 \\
(3 / 21)\end{array}$ & $\begin{array}{l}38.1 \\
(8 / 21)\end{array}$ \\
\hline Urinary assistance & & & & & & & \\
\hline $\begin{array}{l}\text { Wound } \\
\text { medication }\end{array}$ & $\begin{array}{l}33.3 \\
(6 / 18)\end{array}$ & $\begin{array}{l}50 \\
(4 / 8)\end{array}$ & $\mathbf{0}$ & $\begin{array}{l}50 \\
(4 / 8)\end{array}$ & $\begin{array}{l}0 \\
(0 / 5)\end{array}$ & $\mathbf{0}$ & $\mathbf{0}$ \\
\hline & $\begin{array}{l}18.9 \\
(7 / 37)\end{array}$ & $\begin{array}{l}25 \\
(7 / 289)\end{array}$ & $\begin{array}{l}14.3 \\
(4 / 289)\end{array}$ & $\begin{array}{l}39.3 \\
(11 / 28)\end{array}$ & $\begin{array}{l}20 \\
(14 / 70)\end{array}$ & $\begin{array}{l}2.9 \\
(2 / 70)\end{array}$ & $\begin{array}{l}22.9 \\
(16 / 70)\end{array}$ \\
\hline $\begin{array}{l}\text { Contact with body } \\
\text { fluids and injured } \\
\text { skin }\end{array}$ & $\begin{array}{l}29 \\
(9 / 31)\end{array}$ & $\begin{array}{l}26.7 \\
(16 / 60)\end{array}$ & $\begin{array}{l}8.3 \\
(5 / 60)\end{array}$ & $\begin{array}{l}35 \\
(21 / 60)\end{array}$ & $\begin{array}{l}21.2 \\
(14 / 66)\end{array}$ & $\begin{array}{l}7.6 \\
(5 / 66)\end{array}$ & $\begin{array}{l}28.8 \\
(19 / 66)\end{array}$ \\
\hline $\begin{array}{l}\text { Contact with the } \\
\text { patient }\end{array}$ & $\begin{array}{l}14.7 \\
(41 / 279)\end{array}$ & $\begin{array}{l}14 \\
(30 / 214)\end{array}$ & $\begin{array}{l}4.7 \\
(10 / 214)\end{array}$ & $\begin{array}{l}18.7 \\
(40 / 214)\end{array}$ & $\begin{array}{l}15.5 \\
(33 / 213)\end{array}$ & $\begin{array}{l}4.2 \\
(9 / 213)\end{array}$ & $\begin{array}{l}19.7 \\
(42 / 213)\end{array}$ \\
\hline Personal hygiene & $\begin{array}{l}40.5 \\
(30 / 74)\end{array}$ & $\begin{array}{l}41.5 \\
(17 / 41)\end{array}$ & $\begin{array}{l}2.4 \\
(1 / 41)\end{array}$ & $\begin{array}{l}43.9 \\
(18 / 41)\end{array}$ & $\begin{array}{l}21.9 \\
(7 / 32)\end{array}$ & $\begin{array}{l}15.6 \\
(5 / 32)\end{array}$ & $\begin{array}{l}37.5 \\
(12 / 32)\end{array}$ \\
\hline $\begin{array}{l}\text { In direct contact } \\
\text { with the patient }\end{array}$ & $\begin{array}{l}15.2 \\
(57 / 374)\end{array}$ & $\begin{array}{l}13.7 \\
(36 / 263)\end{array}$ & $\begin{array}{l}9.9 \\
(26 / 263)\end{array}$ & $\begin{array}{l}23.6 \\
(62 / 263)\end{array}$ & $\begin{array}{l}16.2 \\
(42 / 259)\end{array}$ & $\begin{array}{l}8.1 \\
(21 / 259)\end{array}$ & $\begin{array}{l}24.2 \\
(63 / 259)\end{array}$ \\
\hline $\begin{array}{l}\text { Hospital } \\
\text { maintenance }\end{array}$ & $\begin{array}{l}35.7 \\
(25 / 70)\end{array}$ & $\begin{array}{l}21.2 \\
(22 / 104)\end{array}$ & $\begin{array}{l}11.5 \\
(12 / 104)\end{array}$ & $\begin{array}{l}32.7 \\
(34 / 104)\end{array}$ & $\begin{array}{l}15.4 \\
(8 / 52)\end{array}$ & $\begin{array}{l}15.4 \\
(8 / 52)\end{array}$ & $\begin{array}{l}30.8 \\
(16 / 52)\end{array}$ \\
\hline
\end{tabular}

$h w=$ hand hygiene; $h r=$ handrubbing 
Table IV: Compliance stratified by activity index (the median value of eight occasions/ hour defines the two categories), in the three study phases

\begin{tabular}{|c|c|c|c|c|c|c|c|c|c|}
\hline \multirow[t]{2}{*}{$\begin{array}{c}\text { Activity index } \\
\text { (occasions/hour) }\end{array}$} & \multicolumn{3}{|c|}{$\begin{array}{c}\text { Compliance } \\
\text { Phase } 1\end{array}$} & \multicolumn{3}{|c|}{$\begin{array}{c}\text { Compliance } \\
\text { Phase } 2\end{array}$} & \multicolumn{3}{|c|}{$\begin{array}{c}\text { Compliance } \\
\text { Phase } 3\end{array}$} \\
\hline & $\%$ & $S D$ & range & $\%$ & $S D$ & Range & $\%$ & $S D$ & range \\
\hline \multicolumn{10}{|c|}{ Intesive Care Area } \\
\hline 0-7 & 36.2 & \pm 22.9 & $0-75$ & 36.6 & \pm 21.5 & $0-67$ & 20.5 & \pm 18.8 & $0-50$ \\
\hline$\geq 8$ & 21.4 & \pm 14.6 & $0-45$ & 23.6 & \pm 16.9 & $0-58$ & 18.3 & \pm 14.3 & $0-45$ \\
\hline \multicolumn{10}{|c|}{ Surgical Area } \\
\hline 0-7 & 22.5 & \pm 26 & $0-75$ & 38.1 & \pm 25.5 & $0-83$ & 32.1 & \pm 25.9 & $0-100$ \\
\hline$\geq 8$ & 11.8 & \pm 7.2 & $0-30$ & 42.27 & \pm 17.6 & $11-80$ & 34.4 & \pm 23.9 & $0-89$ \\
\hline \multicolumn{10}{|c|}{ Medical Area } \\
\hline 0-7 & 27.9 & \pm 33.3 & $0-100$ & 22.4 & \pm 23.7 & $0-83$ & 31.5 & \pm 29.9 & $0-100$ \\
\hline$\geq 8$ & 17.81 & \pm 15.1 & $0-50$ & 17.2 & \pm 14.8 & $0-50$ & 26.3 & \pm 22.5 & $0-100$ \\
\hline \multicolumn{10}{|c|}{ Total } \\
\hline 0-7 & 30.2 & \pm 22.1 & $0-75$ & 31.4 & \pm 26.3 & $0-100$ & 26.7 & \pm 28.2 & $0-100$ \\
\hline$\geq \mathbf{8}$ & 21.8 & \pm 15.5 & $0-58$ & 29.2 & 22.1 & $0-89$ & 20.6 & \pm 18.2 & $0-100$ \\
\hline
\end{tabular}

\section{References}

1. Rotter ML. Hand washing and hand disinfection. In: Mayhall CG, Ed. Hospital Epidemiology and Infection Control. 2nd edn. Philadelphia, PA: Lippincot, Williams \& Wilkins 1999;19391355.

2. Pittet D, Sax H, Hugonnet S, et al. Cost implications of successful hand hygiene promotion. Infect Control Hosp Epidemiol 2004; 25: 264-266.

3. Boyce JM, Pittet D. Guideline for Hand Hygiene in HealthCare Settings - Recommendations of the Healthcare Infection Control Practices Advisory Committee and the HICPAC/SHEA/ APIC/IDSA Hand Hygiene Task Force. Infect Control Hosp Epidemiol 2002; 23: S3-40.

4. Larson EL, Quiros D, Lin SX. Dissemination of the CDC's Hand Hygiene Guideline and impact on infection rates. Am I Infect Control 2007; 35: 666-675.

5. Kampf $\mathrm{G}$. The six golden rules to improve compliance in hand hygiene. J Hosp Infect 2004; 56 Suppl 2: S3-5.
6. NHS, National Patient Safety Agency. Ready, Steady, Go! The full guide to implementing the cleanyourhands campaign in your trust. London 2004. http://www.npsa.nhs.uk/cleanyourhands/ in-the-community/supporting-resources/ [Accessed March 20, 2009].

7. WHO, Word Alliance For Patient Safety. WHO guidelines on Hand Hygiene in Health Care. Geneva 2005. http://www. who.int/patientsafety/events/05/HH_en.pdf [Accessed March 20, 2009].

8. Girou E, Loyeau S, Legrand P, et al. Efficacy of handrubbing with alcohol based solution versus standard handwashing with antiseptic soap: randomised clinical trial. BMJ 2002; 325: 362.

9. Larson E. Handwashing: it's essential - even when you use gloves. Am J Nurs 1989; 89: 934-939.

10. Kim PW, Roghmann MC, Perencevich EN, et al. Rates of hand disinfection associated with glove use, patient isolation, and changes between exposure to various body sites. Am J Infect Control 2003; 31: 97-103 
11. Muto CA, Sistrom MG, Farr BM. Hand hygiene rates unaffected by installation of dispensers of a rapidly acting hand antiseptic. Am J Infect Control 2000; 28: 273-276.

12. Creedon SA. Healthcare workers' hand decontamination practices: compliance with recommended guidelines. J $\mathrm{AdV}$ Nurs 2005; 51: 208-216.

13. Wendt C, Knautz D, von Baum H. Differences in hand hygiene behaviour related to the contamination risk of healthcare activities in different groups of healthcare workers. Infect Control Hosp Epidemiol 2004; 25: 203-206.

14. Doebelling BN, Stanley GL, Sheetz CT, et al. Comparative efficacy of alternative hand-washing agents in reducing nosocomial infections in intensive care units. $N$ Engl / Med 1992; 327: 88-93.
15. Widmer AF. Replace hand washing with use of a waterless alcohol hand rub? Clin Infect Dis 2000; 31:136-143.

16. Pittet D, Mourouga D, Perneger DV, and members of the Infection Control Program. Compliance with handwashing in a teaching hospital. Ann Intern Med 1999; 130: 126-130.

17. Nobile CG, Montuosi P, Diaco E, et al. Health care personnel and hand decontamination in ICU: knowledge, attitudes, and behaviour in Italy. J Hosp Infect 2002; 51: 226-232.

18. Cimiotti JP, Marmur ES, Nesin M, et al. Adverse reactions associated with an alcohol-based hand antiseptic among nurses in a neonatal intensive care unit. Am I Infect Control 2003; 31: 43-8. 